\title{
Quality of clonal plants of Piptocarpha angustifolia in different renewable substrates and seasons of the year
}

\author{
Carlos André Stuepp ${ }^{(1)}$, Ivar Wendling(2), Henrique Soares Koehler ${ }^{(1)}$ and Katia Christina Zuffellato-Ribas ${ }^{(1)}$
}

(1)Universidade Federal do Paraná, Setor de Ciências Agrárias, Rua dos Funcionários, № 1,540, Juvevê, CEP 80035-050 Curitiba, PR, Brazil. E-mail: carlos.stuepp@ufpr.br, koehler@ufpr.br, kazu@ufpr.br (2)Embrapa Florestas, Estrada da Ribeira, Km 111, Guaraituba, Caixa Postal 319, CEP 83411-000 Colombo, PR, Brazil. E-mail: ivar.wendling@embrapa.br

\begin{abstract}
The objective of this work was to evaluate the effect of different compositions of renewable substrates and seasons of the year on the quality of Piptocarpha angustifolia clonal plants. The experiment was carried out in a completely randomized design in a $4 \times 6$ factorial arrangement (four seasons $\mathrm{x}$ six substrate compositions). The analyzed substrates were: S1, commercial substrate with pine bark and coconut fiber base (CF); S2, carbonized rice husk (CRH); S3, fibrous and grainy CF; S4, 50\% CF and 50\% CRH; S5, 30\% $\mathrm{CF}$ and $70 \% \mathrm{CRH}$; and $\mathrm{S} 6,70 \% \mathrm{CF}$ and $30 \% \mathrm{CRH}$. Minicuttings of $8 \pm 1 \mathrm{~cm}$ were planted in tubes of 110 $\mathrm{cm}^{3}$ and placed in a greenhouse, during the four seasons of the year. The evaluated variables were: survival and number of roots at 70 days; survival and emission of shoots at 100 days; rooting, shoot height, stem diameter, and their ratios; easiness of removal from tubes; aggregation to the substrate; and multiplication rate at 130 days. The highest $\mathrm{CRH} / \mathrm{CF}$ ratio favored the development of better-quality plants, and S5 was the most adequate substrate. Spring is more favorable to the survival and quality of cuttings, and, together with summer, favors the highest multiplication rates. The S5 substrate has better physical and chemical quality and improves $P$. angustifolia clonal plants.

Index terms: agro-industrial residues, clonal forestry, forest plant quality, production of minicuttings, "vassourão-branco".

\section{Qualidade de mudas clonais de Piptocarpha angustifolia em diferentes substratos renováveis e estações do ano}

Resumo - O objetivo deste trabalho foi avaliar o efeito de diferentes composições de substratos renováveis e estações do ano na qualidade de mudas clonais de Piptocarpha angustifolia. O experimento foi conduzido em delineamento inteiramente casualizado, em arranjo fatorial 4x6 (quatro estações do ano x seis composições de substratos). Os substratos avaliados foram: S1, substrato comercial à base de casca de pinus e fibra de coco (FC); S2, casca de arroz carbonizada (CAC); S3, FC fibrosa e granulada; S4, 50\% FC e 50\% CAC; S5, 30\% FC e 70\% CAC; e S6, 70\% FC e 30\% CAC. Miniestacas de $8 \pm 1 \mathrm{~cm}$ foram plantadas em tubetes de $110 \mathrm{~cm}^{3} \mathrm{e}$ acondicionadas em casa de vegetação, nas quatro estações do ano. Avaliaram-se as variáveis: sobrevivência e número de raízes aos 70 dias; sobrevivência e emissão de brotos aos 100 dias; enraizamento, altura da parte aérea, diâmetro do coleto e suas relações; facilidade de retirada dos tubetes; agregação ao substrato; e taxa de multiplicação aos 130 dias. A maior relação CAC/FC favoreceu o crescimento de mudas com melhor qualidade, e $\mathrm{S} 5$ foi o substrato mais adequado. A primavera é mais favorável à sobrevivência e à qualidade das mudas e, juntamente com o verão, favorece as maiores taxas de multiplicação. O substrato S5 apresenta melhor qualidade física e química e proporciona melhores mudas clonais de P. angustifolia.

Termos para indexação: resíduos agroindustriais, silvicultura clonal, qualidade de mudas florestais, miniestaquia, vassourão-branco.

\section{Introduction}

The demand for native forest plants has increased considerably in the last decade (Ribeiro-Oliveira \& Ranal, 2014), requiring seedlings and cuttings with greater quality and lower costs (Kratz et al., 2015).
Clonal propagation is an alternative to supply this demand, opening new prospects for species such as Piptocarpha angustifolia Dúsen ex Malme (Asteraceae), pioneer from the mixed rainforest, with great strength and attractive features to the timber industry (Fossati \& Nogueira, 2009; Ferriani et al., 2011). 
The use of minicutting techniques in Eucalyptus species has subsidized the evolution of clonal forestry with increased productivity, standardization of crops, and, especially, qualification of forest products (Brondani et al., 2010; Wendling et al., 2010; Baccarin et al., 2015). For $P$. angustifolia, this technique has proved to be promising, although the obtained results have not been technically feasible because rooting percentages were not greater than $45 \%$ (Ferriani et al., 2011). In addition, the quality of minicuttings also needs to be studied further, for the recommendation of a suitable clonal production system for the species.

Several factors affect the quality of forest cuttings and minicuttings, mainly the physicochemical characteristics of the substrate (Silva et al., 2012; Kratz et al., 2015), besides climatic characteristics, particularly regarding rooting and root vigor (Corrêa et al., 2015). Due to its production steps, the definition of an ideal substrate for clonal propagation is not always simple. In greenhouses under high humidity, the first step is to use a substrate that presents physical characteristics that encourage rooting; the next step, in less controlled environments, is to adopt more complex substrates with greater organic matter content, favoring root development (Mehri et al., 2013).

Since the use of nonrenewable substrates of vegetal and mineral origin, such as peat and vermiculite, respectively, has been increasingly hindered by the high environmental impact of their extraction, more researches are necessary to identify substitutes from renewable sources. Among these, carbonized rice husk and coconut fiber, alone or in combination with other substrates, stand out in the market and are used on a daily basis as renewable products by forestry companies, providing interesting physicochemical characteristics for rooting and plant propagation (Kratz et al., 2015).

It should be noted that physical and chemical characteristics for horticultural substrates show great variation. Overall, $\mathrm{pH}$ should be between 5.0 and 5.8 for substrates with a predominance of organic matter (Kämpf \& Fermino, 2000); electrical conductivity should be below $1.0 \mathrm{mS} \mathrm{cm} \mathrm{cm}^{-1}$ (Gonçalves et al., 2000); apparent density should be between 100-300 $\mathrm{kg} \mathrm{m}^{-3}$ (Kämpf, 2005); and total porosity between $75-85 \%$, with $35-45 \%$ macroporosity and $45-55 \%$ microporosity (Maeda et al., 2007). Other important factors that can affect clonal propagation are water holding capacity and aeration, as well as thermal properties, biological activity, and nutrient availability (Sirin et al., 2010). However, for success in clonal propagation, more research is required to determine the best substrates for each species (Kratz et al., 2015).

The objective of this work was to evaluate the effect of different compositions of renewable substrates and seasons of the year on the quality of $P$. angustifolia clonal plants.

\section{Materials and Methods}

The experiment was conducted between the summer and spring of 2014, i.e., from January to December, at the laboratory for propagation of forest species of Embrapa Florestas, located in the municipality of Colombo, in the state of Paraná, Brazil (2519'17"S, $\left.49^{\circ} 09^{\prime} 39^{\prime \prime} \mathrm{W}\right)$. The miniclonal garden was formed by $P$. angustifolia cuttings produced according to the plant rescue method through epicormic shoots (Stuepp et al., 2014). The cuttings were planted in a semi-hydroponic system with sand and were spaced at $20 \times 20 \mathrm{~cm}$ in May 2013, following the method described in Wendling et al. (2007). Minicuttings were collected at intervals ranging from 18 (summer) to 26 days (winter), and shoots less than $15 \mathrm{~cm}$ in length and with less than three pairs of leaves were kept on the ministumps for subsequent collections over a one-year period. The miniclonal garden was established in a completely randomized design in a split-plot arrangement, with five replicates of ten ministumps each. Over the collections, the evaluated variables were: ministump survival (\%), production of minicuttings per square meter per month and per ministump for a period of 12 months, for 16 subsequent samplings.

The renewable substrate treatments were: S1, commercial substrate with pine bark and coconut fiber (CF) base; S2, carbonized rice husk (CRH); S3, fibrous and grainy $\mathrm{CF}$; S4, 50\% $\mathrm{CF}$ and 50\% $\mathrm{CRH}$; S5, 30\% $\mathrm{CF}$ and $70 \% \mathrm{CRH}$; and $\mathrm{S} 6,70 \% \mathrm{CF}$ and $30 \% \mathrm{CRH}$. The physical and chemical characterization of the substrates was carried out according to Ministério de Agricultura, Pecuária e Abastecimento (Brasil, 2007) (Table 1).

All substrates were manually mixed together with $1.5 \mathrm{~kg} \mathrm{~m}^{-3}$ of the controlled-release fertilizer $\mathrm{N}-\mathrm{P}_{2} \mathrm{O}_{5}-\mathrm{K}_{2} \mathrm{O}$ (15-09-12) and base fertilization: [6.6 $\mathrm{kg} \mathrm{m}^{-3} \mathrm{~N}-\mathrm{P}_{2} \mathrm{O}_{5}-\mathrm{K}_{2} \mathrm{O}$ 4-14-8, $3.3 \mathrm{~kg} \mathrm{~m}^{-3}$ superphosphate 
$\left(20 \% \mathrm{P}_{2} \mathrm{O}_{5}\right.$ and $\left.14 \% \mathrm{SO}_{4}\right)$, and $0.8 \mathrm{~kg} \mathrm{~m}^{-3}$ FTE BR12 (9\% $\mathrm{Zn}, 3 \% \mathrm{Fe}, 2 \% \mathrm{Mn}, 0.1 \% \mathrm{Mo}, 1.8 \% \mathrm{~B}$, and $0.8 \%$ $\mathrm{Cu})$. Minicuttings with $8 \pm 1 \mathrm{~cm}$ in length and average diameter of $0.5 \pm 0.1 \mathrm{~cm}$ were prepared, keeping up to two leaves reduced to $50 \%$ of their original surface. The minicuttings were planted about $1 \mathrm{~cm}$ deep in polypropylene tubes with $110 \mathrm{~cm}^{3}$ capacity, which were filled with the evaluated substrates and then placed in a greenhouse with intermittent mist (average temperature of $24 \pm 2{ }^{\circ} \mathrm{C}$ and $85 \%$ relative humidity). After 70 days, the minicuttings were transferred to a shade house with $50 \%$ shade and subjected to three daily micro-spray irrigations of 10 min with a flow of $144 \mathrm{~L}$ per hour. Then, the minicuttings were taken to a rustication area, where they were subjected to four daily irrigations of 30 min with a flow rate of $97 \mathrm{~L}$ per hour, under full sunlight conditions for 30 days (Figure 1).

The assessed variables were: survival (live minicuttings with active vegetative aspect when taken from the greenhouse) and root emission on the tube base (percentage of minicuttings that had at least one root emerging from the bottom of the plastic tube) at 70 days; survival (percentage of live minicuttings with active vegetative aspect when taken from the shade house) and emission of shoots (percentage of minicuttings with new shoots of at least 2-mm length) at 100 days; rooting (percentage of minicuttings with at least one root), shoot height (length in centimeters of the main sprout), stem diameter (in millimeters), easiness of removal from tubes (ERT), aggregation to the substrate (AG), and multiplication rate at 130 days under full sunlight conditions. Evaluations of ERT and AG were carried out according to Wendling et al. (2007).

When the survivor minicuttings, at 130 days after installation (DAI), were considered rooted, the multiplication rate of minicuttings per square meter per month was calculated for each substrate, using the following equation (Wendling et al., 2015): $\mathrm{MR}=$ PPSM $\left(\mathrm{m}^{2}\right.$ per month $) \times$ rooting percentage, in which MR is the multiplication rate and PPSM is the production of minicuttings per square meter per month.

The minicutting experiments were conducted in a completely randomized design in a $4 \times 6$ factorial arrangement (four seasons of the year $\mathrm{x}$ six substrates), with five replicates of 16 minicuttings per experimental unit on the following dates, in 2014: January 30 in summer; April 29 in autumn; July 28 in winter; and November 29 in spring. The variances of the treatments were evaluated by Bartlett's test for homogeneity, and the means of the variables with significant differences by the F-test were compared by Tukey's test, at $5 \%$ probability.

Table 1. Physical and chemical characteristics of the renewable substrates for Piptocarpha angustifolia minicuttings ${ }^{(1)}$.

\begin{tabular}{|c|c|c|c|c|c|c|}
\hline Characteristics & S1 & S2 & S3 & $\mathrm{S} 4$ & S5 & S6 \\
\hline $\mathrm{pH} \mathrm{H} \mathrm{H}_{2} \mathrm{O}$ & 4.20 & 5.25 & 7.36 & 4.91 & 5.21 & 5.72 \\
\hline Electrical conductivity $\left(\mathrm{mS} \mathrm{cm}^{-1}\right)$ & 1.26 & 0.35 & 0.08 & 0.75 & 0.49 & 0.26 \\
\hline Wet density $\left(\mathrm{mS} \mathrm{cm}^{-1}\right)$ & 409.47 & 126.33 & 148.01 & 185.42 & 208.46 & 133.06 \\
\hline Apparent density $\left(\mathrm{kg} \mathrm{m}^{-3}\right)$ & 198.07 & 81.02 & 102.95 & 109.46 & 122.46 & 90.43 \\
\hline Apparent humidity $\left(\mathrm{kg} \mathrm{m}^{-3}\right)$ & 51.62 & 35.86 & 30.21 & 40.97 & 41.26 & 32.06 \\
\hline Total porosity $\left(\mathrm{kg} \mathrm{m}^{-3}\right)$ & 80.37 & 82.08 & 81.7 & 81.02 & 80.38 & 82.29 \\
\hline Macroporosity (\%) & 10.29 & 21.95 & 64.3 & 27.88 & 41.27 & 36.05 \\
\hline Microporosity (\%) & 34.75 & 29.97 & 10.03 & 20.96 & 17.24 & 24.16 \\
\hline Easily available water (\%) & 31.04 & 27.09 & 7.25 & 29.63 & 20.75 & 19.9 \\
\hline Buffering water (\%) & 4.29 & 3.07 & 0.11 & 2.55 & 1.12 & 2.18 \\
\hline WRC $10(\%)$ & 70.08 & 60.13 & 17.39 & 53.14 & 39.11 & 46.24 \\
\hline WRC $50(\%)$ & 39.04 & 33.04 & 10.14 & 23.51 & 18.36 & 26.34 \\
\hline WRC $100(\%)$ & 34.75 & 29.97 & 10.03 & 20.96 & 17.24 & 24.16 \\
\hline $\operatorname{TSSC}\left(\mathrm{g} \mathrm{L}^{-1}\right)$ & 1.56 & 0.13 & 0.04 & 0.42 & 0.29 & 0.11 \\
\hline
\end{tabular}

${ }^{(1)} \mathrm{S} 1$, commercial substrate with pine bark and coconut fiber (CF) base; S2, carbonized rice husk (CRH); 33 , fibrous and grainy $\mathrm{CF}$; $\mathrm{S} 4,50 \% \mathrm{CF}$ and $50 \%$ $\mathrm{CRH}$; S5, 30\% CF and 70\% CRH; S6, 70\% CF and 30\% CRH; WRC 10, WRC 50, and WRC 100, water retention capacity under suction of 10, 50, and $100 \mathrm{~cm}$ of water column, respectively; and TSSC, total soluble salts content. 


\section{Results and Discussion}

After 16 collections, totaling one year, the survival of the ministumps (82.6\%) remained high (Figure 2), taking into account the long trial period and the fact that the dead ministumps were not replanted in the miniclonal garden. There was no effect of seasons on ministump survival; however, there was a slight reduction in survival associated with the lower intervals between the collections of the minicuttings. This effect is possibly related with the shorter period available for the recovery of the ministumps between successive collections (Stuepp et al., 2015).

Summer presented a higher PPSM (303.1) than that of the other evaluated seasons, which was favored by the increase in average temperatures (Figure 3). These results are an indicator of the effectiveness of the semihydroponic system and nutrient solution applied to the ministumps, in alignment with the results obtained by Ferriani et al. (2011) for P. angustifolia productivity, with 6.7 minicuttings per ministump at intervals of 30 days in spring.

The beginning of the collections took place when the miniclonal garden was already formed and in peak productivity, approximately 12 months after its installation, and did not reflect the effects of the adjustment of the ministumps to the semi-hydroponic system, generating greater homogeneity in minicutting productivity. Despite the reduction in productivity observed in autumn and winter, the results were significant, allowing the four collections per season (Figure 3).

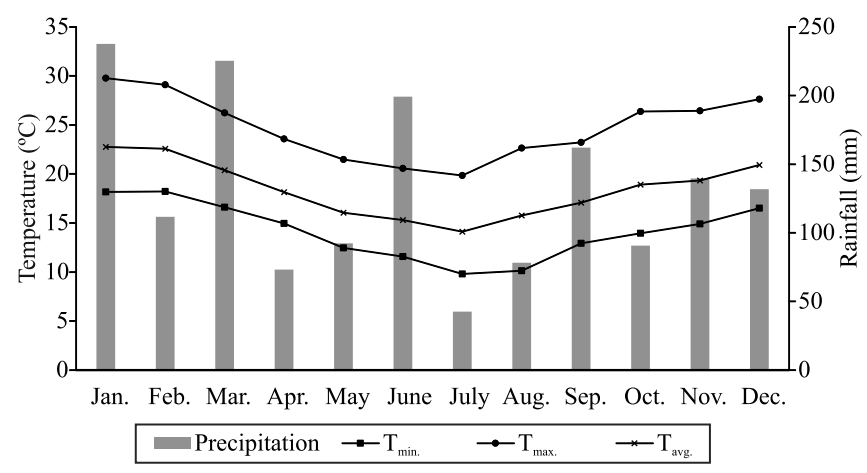

Figure 1. Means of minimum $\left(\mathrm{T}_{\text {Min. }}\right)$, maximum $\left(\mathrm{T}_{\text {Max. }}\right)$, and average $\left(\mathrm{T}_{\mathrm{Avg}}\right)$ temperatures and of rainfall for the municipality of Colombo, in the state of Paraná, Brazil, between January 2014 and December 2014. Source: Simepar (2015).
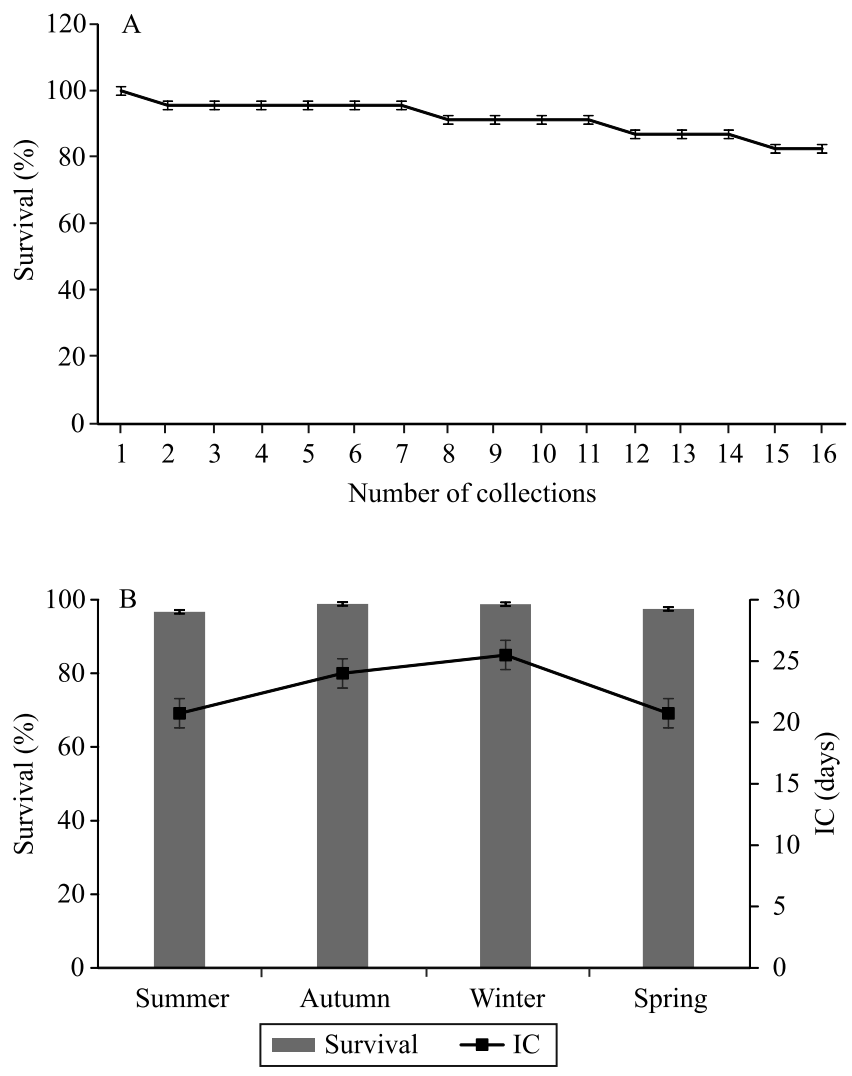

Figure 2. Survival of Piptocarpha angustifolia minicuttings during 353 days of successive collections in function of: A, number of collections; and B, seasons of the year and data collection intervals (IC). Bars indicate the mean standard error.

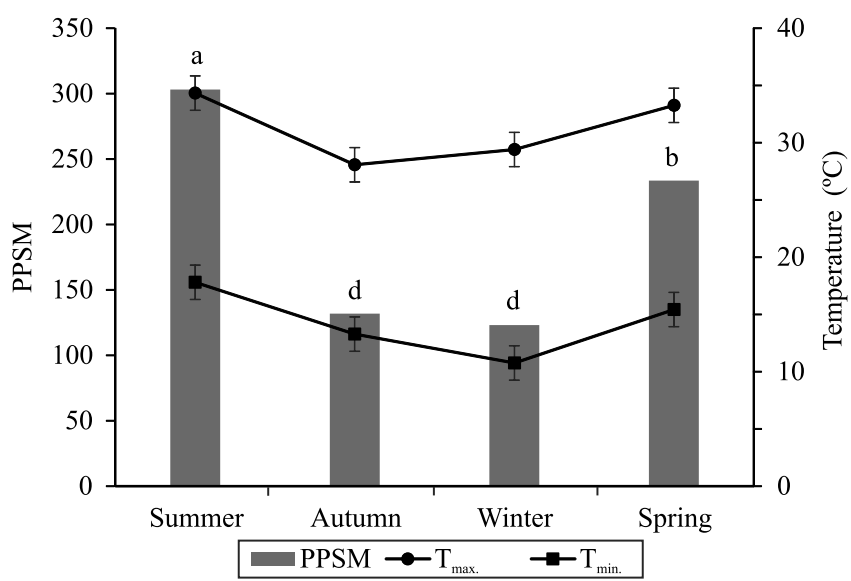

Figure 3. Production of Piptocarpha angustifolia minicuttings per square meter (PPSM) according to seasons of the year. Means followed by equal letters do not differ by Tukey's test, at 5\% probability. Bars indicate the mean

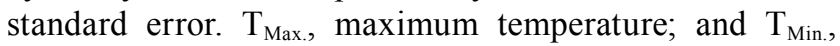
minimum temperature. 
Survival at greenhouse exit (SEGH) at $70 \mathrm{DAI}$, at shade house exit (SESH) at $100 \mathrm{DAI}$, and rooting under full sunlight (RFS) at 130 DAI showed the significant effect of the evaluated substrates; in general, the compositions with $\mathrm{CRH}$ and $\mathrm{CF}$, i.e., S4, S5, and S6, had higher values for SEGH than S1 and S2, for SESH than S1 and S3, and for RFS than S1, S2, and S3 (Figure 4). Authors have emphasized the effects of different substrate compositions and of their physical and chemical properties on the rooting and quality of clonal plants, particularly of those difficult to root (Brondani et al., 2007; Silva et al., 2012).

The reduction of SEGH in S1 (75\%) possibly resulted from an imbalance in the physical (wet density, macroand microporosity) (Maeda et al., 2007) and chemical
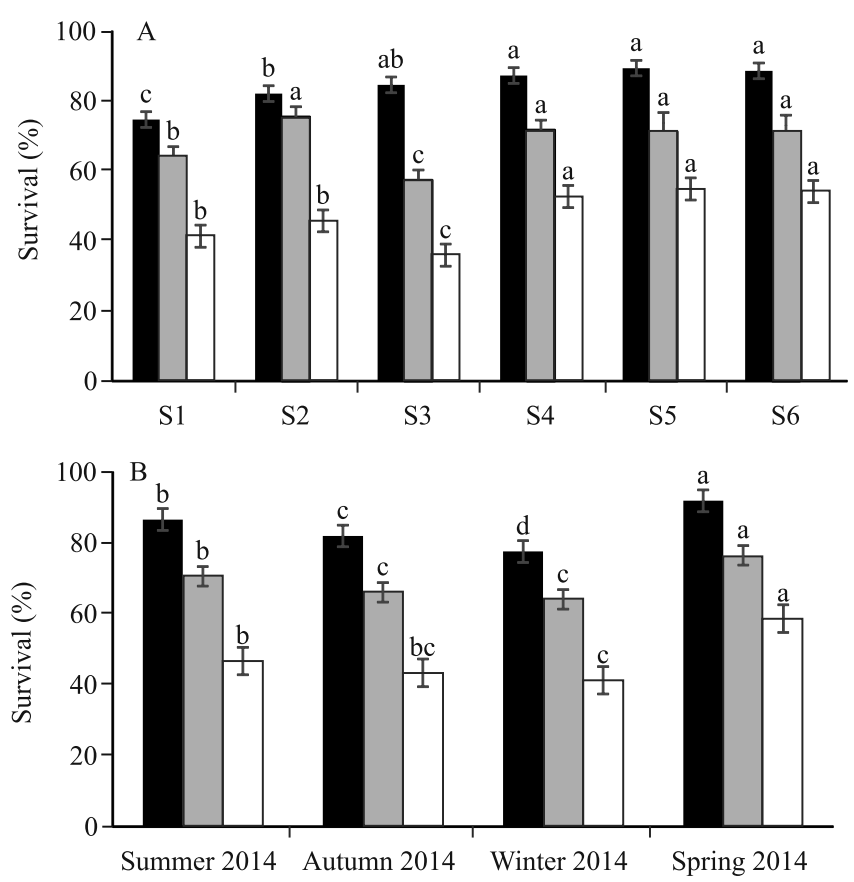

- SEGH $\square$ SESH $\square$ RFS

Figure 4. Survival of Piptocarpha angustifolia minicuttings at greenhouse exit (SEGH) at 70 days after installation (DAI), at shade house exit (SESH) at $100 \mathrm{DAI}$, and rooting under full sunlight (RFS) at 130 DAI according to substrate composition (A) and seasons of the year (B). S1, commercial substrate with pine bark and coconut fiber (CF) base; S2, carbonized rice husk (CRH); S3, fibrous and grainy CF; S4, $50 \% \mathrm{CF}$ and $50 \% \mathrm{CRH} ; \mathrm{S} 5,30 \% \mathrm{CF}$ and $70 \% \mathrm{CRH}$; and $\mathrm{S} 6$, $70 \% \mathrm{CF}$ and $30 \% \mathrm{CRH}$. Columns with equal letters do not differ by Tukey's test, at $5 \%$ probability. Bars indicate the mean standard error.
( $\mathrm{pH}$, electrical conductivity, and total content of soluble salts) characteristics of the substrate (Gonçalves et al., 2000), all strongly affected by the high humidity in the greenhouse (Table 1). This shows the importance of the requirements for substrate physical characteristics for vegetative propagation, especially with respect to porosity, in order to ensure the adequate availability of oxygen for root emission and development in high humidity environments, such as greenhouses (Sirin et al., 2010; Silva et al., 2012).

The mortality observed in S3 when the minicuttings were taken from the shade house $(55.8 \%)$ was higher than under full sunlight (35.9\%) (Figure 4). The high $\mathrm{pH}$ found is possibly one of the factors negatively affecting the survival of the minicuttings in this substrate, which shows high macroporosity (64.3\%) and, consequently, reduced easily available water $(7.36 \%)$, buffer water $(0.11 \%)$, and water retention capacity (Table 1$)$. This makes it difficult to maintain the necessary moisture for the development of plants outside the greenhouse.

$\mathrm{CRH}$ has been increasingly used in the composition of substrates for plant propagation, providing excellent drainage, good root oxygenation, relative structural stability, low density, and $\mathrm{pH}$ close to neutrality (Caldeira et al., 2013). It should be noted that all these physical characteristics associated with $\mathrm{CRH}$ are dependent on particle size and on the combination with other components (Kratz et al., 2015), which means this substrate may not respond well when used alone.

Regarding seasons of the year, spring was superior in all periods, with $58.7 \%$ survival at 130 DAI (Figure 4), corroborating the results obtained by Ferriani et al. (2011), who used the minicutting technique for cloning $P$. angustifolia and reported $45 \%$ rooting in spring. These authors also observed good results for minicutting rooting and consequent survival throughout the experiment, which can also be associated with the juvenility of the used propagules.

Root emission on tube base at 70 DAI and sprout emission at 100 DAI were affected by substrates, with the best results in S2, S4, S5, and S6 (Figure 5). This can probably be attributed to the best adaptation of these substrates within the range of recommended physical and chemical characteristics (Gonçalves et al., 2000; Kämpf \& Fermino, 2000; Maeda et al., 2007).

Concerning seasons, the effect of the increase in average temperatures is clear during spring and summer on sprout emission and, more precisely, during summer 
on root vigor (Figure 5). Consequently, the reduced temperatures in winter resulted in lower percentages for both variables. The multiplication rate reveals a significant interaction between seasons and substrate compositions, with significant effect of high PPSM in summer and spring, qualifying the S4, S5, and S6 substrates, with mixed compositions of CRH and CF, and the S2 substrate, composed only of CF (Table 2). The multiplication rate may represent the technical efficiency of the species for clonal propagation, since it can express real plant productivity, generating conditions for a proper sizing of the production system at commercial level (Wendling et al., 2015).

For height and stem diameter, an interaction was observed between the evaluated substrates and
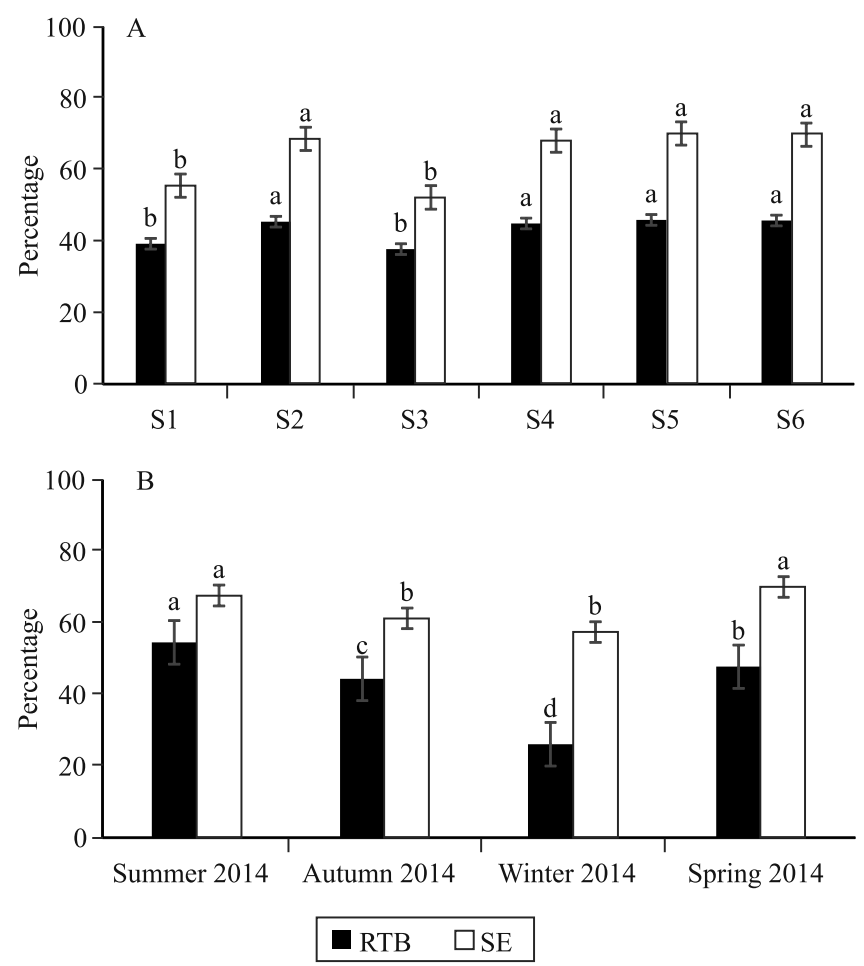

Figure 5. Root emission on tube base (RTB) at 70 days after installation (DAI) and sprout emission (SE) at 100 DAI of Piptocarpha angustifolia minicuttings according to substrate composition (A) and seasons of the year (B). S1, commercial substrate with pine bark and coconut fiber (CF) base; S2, carbonized rice husk (CRH); S3, fibrous and grainy $\mathrm{CF} ; \mathrm{S} 4,50 \% \mathrm{CF}$ and $50 \% \mathrm{CRH}$; $\mathrm{S} 5,30 \% \mathrm{CF}$ and $70 \% \mathrm{CRH}$; and $\mathrm{S} 6,70 \% \mathrm{CF}$ and $30 \% \mathrm{CRH}$. Columns with equal letters do not differ by Tukey's test, at $5 \%$ probability. Bars indicate the mean standard error. seasons, highlighting the mixed composition of the S4, S5, and S6 substrates. Regarding height, S5 showed the best results in summer and spring. However, for stem diameter, the best results were obtained in the S4, S5, and $\mathrm{S} 6$ substrates in summer and in S4 in spring (Table 2). The use of $\mathrm{CF}$ or $\mathrm{CRH}$, as well as of the commercial substrate, did not favor plant growth. However, the increase of the $\mathrm{CRH} / \mathrm{CF}$ ratio favored the growth in height, which reached the highest values in the $70 \%$ $\mathrm{CRH} / 30 \% \mathrm{CF}$ ratio (S5). Therefore, $\mathrm{S} 5$ was the substrate with the highest number of chemical and physical properties within the standards established by other authors, including $\mathrm{pH}$, electrical conductivity, apparent density, total porosity, macro- and microporosity, easily available water (EAW), and total soluble salts content (Kämpf \& Fermino, 2000; Gonçalves et al., 2000; Kämpf, 2005; Maeda et al., 2007).

Despite having a common composition for forest plant propagation, the commercial substrate with pine bark and CF base (S1) was not efficient for $P$. angustifolia clonal propagation. Among the main physical and chemical characteristics that possibly affect its performance, are low $\mathrm{pH}$, macroand microporosity, and high values for electrical conductivity, easily available water, and total content of soluble salts (Table 1).

For $P$. angustifolia clonal propagation, stem diameter alone is not a good variable to express final plant quality, mainly because the initial diameter of the minicuttings is already high, about $5 \mathrm{~mm}$, which makes the analysis of this variable difficult. However, stem diameter is a key variable for evaluating survival potential and post-planting growth (Silva et al., 2012), and there is evidence that, within the same species, plants with larger stem diameter tend to present greater root growth in the field (Souza et al., 2006).

Similarly, the ratio between height and stem diameter (H/SD) can also indicate or not a proportionate plant growth. Besides being a good reference parameter for reserve accumulation, it may also represent a greater plant resistance and fixation to the substrate (Artur et al., 2007). However, in clonal forestry, the diameter between species and clones varies greatly. For this reason, this analysis becomes complicated for $P$. angustifolia, when using minicuttings with an average diameter of $5 \mathrm{~mm}$, unlike for Eucalyptus clones in which this relationship can be set to optimum values between 6 and $10 \mathrm{~mm}$ (Gomes et al., 2002). 
Regardless of the analyzed substrates, ERT was adequate. However, regarding seasons, this rate was higher in those with mild temperatures, that is, in autumn and winter, differing significantly only in summer, due to the lower formation and development of roots in the cooler seasons (Figure 6). Similarly, the best results for root aggregation to the substrate (RAS) were obtained in S4 and S5, which differed significantly from the other substrates, although a good result was also verified in S6; together these three substrates were superior to the other ones. Summer had the highest value for RAS, in comparison with the other seasons, except spring, without significant variations.

A good RAS is an excellent indicator of the quality of forest cuttings and minicuttings, ensuring that they come to the field with the same quality they had when taken out of the nursery. Wendling et al. (2007) used a scale of 0 to 10 to assess the production of Ilex paraguariensis seedlings in plastic tubes and found greater survival capacity of these plants in the field at values closer to 10 . The definition of basic standards for nondestructive evaluation methods before plants are removed from nurseries can be an effective tool to qualify the propagation of plant forest species (Silva et al., 2015). Therefore, the selection of plants based on these morphological variables suggests exceptional gains in productivity and quality.

The effects of the physical and chemical characteristics of the substrates on rooting, root vigor, and final quality of $P$. angustifolia plants was shown in the present study, as well as the technical feasibility of the clonal propagation of the species, opening new prospects for its use either for timber production or for the restoration of degraded ecosystems.

Table 2. Multiplication rate, height, and stem diameter of Piptocarpha angustifolia minicuttings at 130 days after installation (DAI) according to substrate composition and seasons of the year ${ }^{(1)}$.

\begin{tabular}{|c|c|c|c|c|c|}
\hline Substrate $(2)$ & Summer & Autumn & Winter & Spring & Means \\
\hline \multicolumn{6}{|c|}{ Multiplication rate } \\
\hline S1 & $103.9 \mathrm{aB}$ & $51.0 \mathrm{bAB}$ & $40.2 \mathrm{bA}$ & $122.2 \mathrm{aBC}$ & 79.3 \\
\hline $\mathrm{S} 2$ & $157.7 \mathrm{aA}$ & $68.1 \mathrm{bA}$ & $55.0 \mathrm{bA}$ & $143.3 \mathrm{aAB}$ & 106.0 \\
\hline S3 & $87.8 \mathrm{bB}$ & $40.4 \mathrm{cB}$ & $45.2 \mathrm{cA}$ & $110.6 \mathrm{aC}$ & 71.0 \\
\hline S4 & $151.7 \mathrm{aA}$ & $61.5 \mathrm{bAB}$ & $58.7 \mathrm{bA}$ & $146.4 \mathrm{aA}$ & 104.6 \\
\hline S5 & $159.4 \mathrm{aA}$ & $65.5 \mathrm{bA}$ & $58.7 \mathrm{bA}$ & $153.3 \mathrm{aA}$ & 109.2 \\
\hline S6 & $158.3 \mathrm{aA}$ & $66.8 \mathrm{bA}$ & $57.5 \mathrm{bA}$ & $147.1 \mathrm{aA}$ & 107.4 \\
\hline Means & 136.5 & 58.9 & 52.5 & 137.1 & - \\
\hline Coefficient of variation (\%) & & & 12.54 & & \\
\hline \multicolumn{6}{|c|}{ Height $(\mathrm{cm})$} \\
\hline S1 & $14.5 \mathrm{aCD}$ & $12.9 \mathrm{aBC}$ & $12.0 \mathrm{aCD}$ & $12.6 \mathrm{aC}$ & 13.0 \\
\hline S2 & $12.4 \mathrm{aD}$ & $11.1 \mathrm{aC}$ & $10.8 \mathrm{aD}$ & $10.9 \mathrm{aC}$ & 11.3 \\
\hline S3 & $11.7 \mathrm{aD}$ & $12.2 \mathrm{aC}$ & $11.0 \mathrm{aD}$ & $10.1 \mathrm{aC}$ & 11.3 \\
\hline S4 & $21.4 \mathrm{aB}$ & $18.1 \mathrm{bcA}$ & $15.9 \mathrm{cAB}$ & $20.6 \mathrm{abB}$ & 19.0 \\
\hline S5 & $25.9 \mathrm{aA}$ & $20.2 \mathrm{bA}$ & $17.9 \mathrm{bA}$ & $23.9 \mathrm{aA}$ & 22.0 \\
\hline S6 & 17.1abC & $15.2 \mathrm{bcB}$ & $14.2 \mathrm{cBC}$ & $18.3 \mathrm{aB}$ & 16.2 \\
\hline Means & 17.2 & 15.0 & 13.6 & 16.1 & - \\
\hline Coefficient of variation (\%) & & & 9.72 & & \\
\hline \multicolumn{6}{|c|}{ Stem diameter $(\mathrm{mm})$} \\
\hline S1 & $5.5 \mathrm{aB}$ & $4.3 \mathrm{bC}$ & $4.0 \mathrm{bB}$ & $4.3 \mathrm{bD}$ & 4.5 \\
\hline S2 & $5.7 \mathrm{aB}$ & $4.6 \mathrm{bBC}$ & $4.4 \mathrm{bAB}$ & $4.7 \mathrm{bCD}$ & 4.8 \\
\hline S3 & $5.5 \mathrm{aB}$ & $4.4 \mathrm{bC}$ & $4.3 \mathrm{bB}$ & $4.3 \mathrm{bD}$ & 4.6 \\
\hline S4 & 7.6aA & 5.1bABC & $4.9 \mathrm{bAB}$ & $7.4 \mathrm{aA}$ & 6.3 \\
\hline S5 & $7.2 \mathrm{aA}$ & $5.7 \mathrm{bcAB}$ & $5.1 \mathrm{cAB}$ & 6.4abAB & 6.1 \\
\hline S6 & $8.1 \mathrm{aA}$ & $6.1 \mathrm{bA}$ & $5.5 \mathrm{bA}$ & $5.7 \mathrm{bBC}$ & 6.3 \\
\hline Means & 6.6 & 5.0 & 4.7 & 5.5 & - \\
\hline Coefficient of variation (\%) & & & 11.82 & & \\
\hline
\end{tabular}



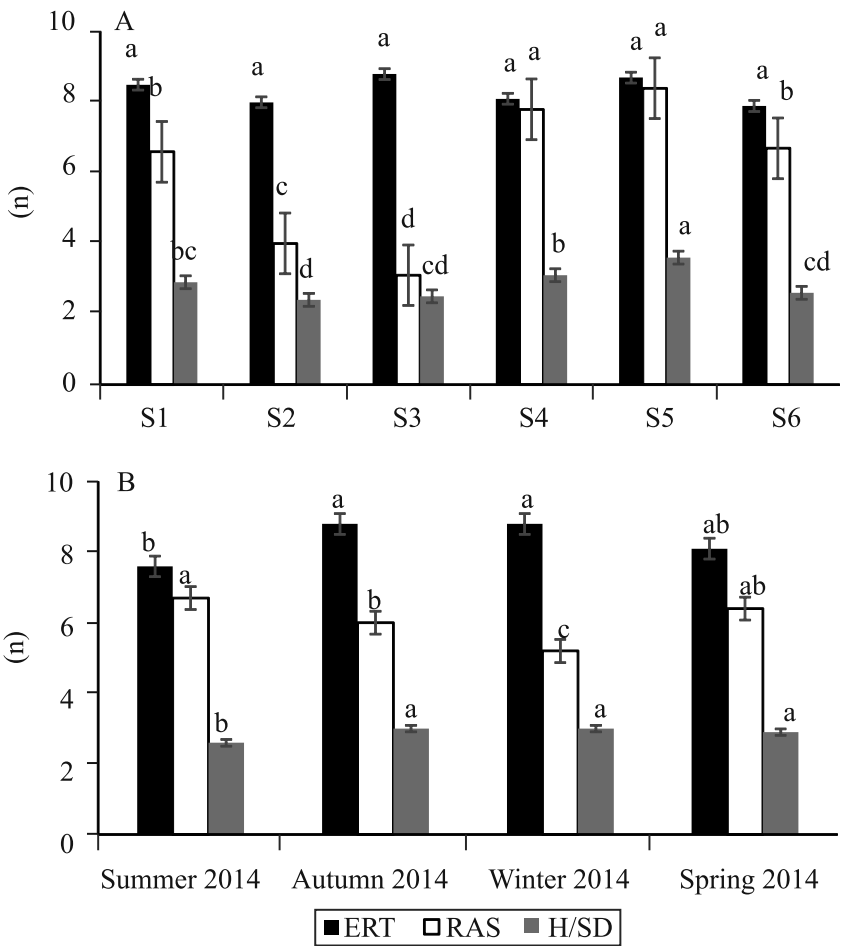

Figure 6. Easiness of removal from tubes (ERT), root aggregation to the substrate (RAS), and ratio between shoot height and stem diameter (H/SD) at 130 days after installation of Piptocarpha angustifolia minicuttings according to substrate composition (A) and seasons of the year (B). S1, commercial substrate with pine bark and coconut fiber (CF) base; S2, carbonized rice husk (CRH); $\mathrm{S} 3$, fibrous and grainy CF; S4, 50\% CF and 50\% CRH; S5, $30 \% \mathrm{CF}$ and $70 \% \mathrm{CRH}$; and $\mathrm{S} 6,70 \% \mathrm{CF}$ and $30 \% \mathrm{CRH}$. Columns with equal letters do not differ by Tukey's test, at $5 \%$ probability. Bars indicate the mean standard error.

\section{Conclusions}

1. Substrates of mixed compositions with increased proportions of carbonized rice husk and coconut fiber favor Piptocarpha angustifolia production and higher plant quality.

2. Spring is the most favorable season for plant survival and quality, and, together with summer, shows the highest multiplication rates for minicuttings.

3. The S5 substrate has better physical and chemical quality and improves $P$. angustifolia clonal plants.

\section{Acknowledgments}

To Coordenação de Aperfeiçoamento de Pessoal de Nível Superior (Capes), for financial support; and to
Sistema Meteorológico do Paraná (Simepar), for data on temperature and humidity for the municipality of Colombo, in the state of Paraná, Brazil.

\section{References}

ARTUR, A.G.; CRUZ, M.C.P. da; FERREIRA, M.E.; BARRETTO, V.C. de M.; YAGI, R. Esterco bovino e calagem para formação de mudas de guanandi. Pesquisa Agropecuária Brasileira, v.42, p.843-850, 2007. DOI: 10.1590/S0100$204 X 2007000600011$.

BACCARIN, F.J.B.; BRONDANI, G.E.; ALMEIDA, L.V. de; VIEIRA, I.G.; OLIVEIRA, L.S. de; ALMEIDA, M. de. Vegetative rescue and cloning of Eucalyptus benthamii selected adult trees. New Forests, v.46, p.465-483, 2015. DOI: 10.1007/s11056-0159472-x.

BRASIL. Ministério da Agricultura, Pecuária e Abastecimento. Instrução Normativa SDA n ${ }^{\circ}$ 17, de 21 de maio de 2007. [Aprova os métodos analíticos oficiais para análise de substratos e condicionadores de solos, na forma do Anexo à presente Instrução Normativa]. Diário Oficial [da] República Federativa do Brasil, Brasília 24 maio 2007. Seção 1, p.8-9.

BRONDANI, G.E.; GROSSI, F.; WENDLING, I.; DUTRA, L.F.; ARAUJO, M.A. Aplicação de IBA para o enraizamento de miniestacas de Eucalyptus benthamii Maiden \& Cambage $\mathrm{x}$ Eucalyptus dunnii Maiden. Acta Scientiarum. Agronomy, v.32, p.667-674, 2010. DOI: 10.4025/actasciagron.v32i4.4879.

BRONDANI, G.E.; WENDLING, I.; SANTIN, D.; BENEDETTI, E.L.; ROVEDA, L.F.; ORRUTÉA, A.G. Ambiente de enraizamento e substratos na miniestaquia de erva-mate. Scientia Agraria, v.8, p.257-267, 2007. DOI: 10.5380/rsa.v8i3.9540.

CALDEIRA, M.V.W.; DELARMELINA, W.M.; FARIA, J.C.T.; JUVANHOL, R.S. Substratos alternativos na produção de mudas de Chamaecrista desvauxii. Revista Árvore, v.37, p.31-39, 2013. DOI: 10.1590/S0100-67622013000100004.

CORRÊA, P.R.R.; SCHUlTZ, B.; AUER, C.G.; HIGA, A.R. Efeito da planta matriz, estação do ano e ambiente de cultivo na miniestaquia de Pinus radiata. Floresta, v.45, p.65-74, 2015. DOI: 10.5380/rf.v45i1.32793.

FERRIANI, A.P.; ZUFFELLATO-RIBAS, K.C.; HELM, C.V.; BOZA, A.; WENDLING, I.; KOEHLER, H.S. Produção de brotações e enraizamento de miniestacas de Piptocarpha angustifolia. Pesquisa Florestal Brasileira, v.31, p.257-264, 2011. DOI: 10.4336/2011.pfb.31.67.257.

FOSSATI, L.C.; NOGUEIRA, A.C. Qualidade física e fisiológica das cipselas de Piptocarpha angustifolia Dusén ex Malme de diferentes populações e árvores porta-sementes. Floresta, v.39, p.419-430, 2009. DOI: 10.5380/rf.v39i2.14569.

GOMES, J.M.; COUTO, L.; LEITE, H.G.; XAVIER, A.; GARCIA, S.L.R. Parâmetros morfológicos na avaliação da qualidade de mudas de Eucalyptus grandis. Revista Árvore, v.26, p.655-664, 2002. DOI: 10.1590/S0100-67622002000600002.

GONÇALVES, J.L. de M.; SANTARELLI, E.D.; MORAES NETO, S.P.; MANARA, M.P. Produção de mudas de espécies 
nativas: substrato, nutrição, sombreamento e fertilização. In: GONÇALVES, J.L. de M.; BENEDETTI, V. (Ed.). Nutrição e fertilização florestal. Piracicaba: IPEF, 2000. p.309-350.

KÄMPF, A.N. Substrato. In: KAMPF, A.N. Produção comercial de plantas ornamentais. 2.ed. Guaíba: Agrolivros, 2005. p.45-72.

KÄMPF, A.N.; FERMINO, M.H. (Ed.). Substratos para plantas: a base da produção vegetal em recipientes. Porto Alegre: Genesis, 2000. 312p.

KRATZ, D.; PIRES, P.P.; STUEPP, C.A.; WENDLING, I. Produção de mudas de erva-mate por miniestaquia em substratos renováveis. Revista Floresta, v.45, p.609-616, 2015. DOI: 10.5380/rf.v45i3.36531.

MAEDA, S.; DEDECEK, R.A.; AGOSTINI, R.B.; ANDRADE, G. de C.; SILVA, H.D. da. Caracterização de substratos para produção de mudas de espécies florestais elaborados a partir de resíduos orgânicos. Pesquisa Florestal Brasileira, n.54, p.97104, 2007.

MEHRI, H.; MHANNA, K.; SOLTANE, A. Root growth of Arbequina cuttings as influenced by organic and inorganic substrates under the conditions of Al-Jouf (KSA). American Journal of Plant Physiology, v.8, p.74-83, 2013. DOI: 10.3923/ ajpp.2013.74.83.

RIBEIRO-OLIVEIRA, J.P.; RANAL, M.A. Sementes florestais brasileiras: início precário, presente inebriante e o future, prommissor? Ciência Florestal, v.24, p.771-784, 2014. DOI: 10.1590/1980-509820142403024.

SILVA, C.R.A.; RIBEIRO, A.; OLIVEIRA, A.S. de; KLIPPEL, V.H.; BARBOSA, R.L.P. Desenvolvimento biométrico de mudas de eucalipto sob diferentes lâminas de irrigação na fase de crescimento. Pesquisa Florestal Brasileira, v.35, p.381-390, 2015. DOI: $10.4336 / 2015 . p f b .35 .84 .897$.

SILVA, R.B.G. da; SIMÕES, D.; SILVA, M.R. da. Qualidade de mudas clonais de Eucalyptus urophylla x E. grandis em função do substrato. Revista Brasileira de Engenharia Agrícola e Ambiental, v.16, p.297-302, 2012. DOI: 10.1590/S141543662012000300010.

SIMEPAR. Sistema Meteorológico do Paraná. Dados meteorológicos de Curitiba: ano 2014. Curitiba: Simepar, 2015. Disponível em: <http://www.simepar.br/site2/faleconosco $>$. Accessed on: Nov. 172015.

SIRIN, U.; ERTAN, E.; ERTAN, B. Growth substrates and fig nursery tree production. Scientia Agricola, v.67, p.633-638, 2010. DOI: $10.1590 / \mathrm{S} 0103-90162010000600003$.

SOUZA, C.A.M. de; OLIVEIRA, R.B. de; MARTINS FILHO, S.; LIMA, J.S. de S. Crescimento em campo de espécies florestais em diferentes condições de adubações. Ciência Florestal, v.16, p.243-249, 2006. DOI: 10.5902/198050981905.

STUEPP, C.A.; ZUFFELLATO-RIBAS, K.C.; KOEHLER, H.S.; WENDLING, I. Rooting mini-cuttings of Paulownia fortunei var. Mikado derived from clonal mini-garden. Revista Árvore, v.39, p.497-504, 2015. DOI: 10.1590/0100-67622015000300010.

STUEPP, C.A.; ZUFFELLATO-RIBAS, K.C.; WENDLING, I.; KOEHLER, H.S.; BONA, C. Vegetative propagation of mature dragon trees through epicormic shoots. Bosque, v.35, p.333-345, 2014. DOI: $10.4067 / \mathrm{s} 0717-92002014000300008$.

WENDLING, I.; BRONDANI, G.E.; DUTRA, L.F.; HANSEL, F.A. Mini-cuttings technique: a new ex vitro method for clonal propagation of sweetgum. New Forests, v.39, p.343-353, 2010. DOI: $10.1007 / \mathrm{s} 11056-009-9175-2$.

WENDLING, I.; BROOKS, P.R.; TRUEMAN, S.J. Topophysis in Corymbia torelliana x C. citriodora seedlings: adventitious rooting capacity, stem anatomy, and auxin and abscisic acid concentrations. New Forests, v.46, p.107-120, 2015. DOI: 10.1007/ s11056-014-9451-7.

WENDLING, I.; GUASTALA, D.; DEDECEK, R. Características físicas e químicas de substratos para produção de mudas de Ilex paraguariensis St. Hil. Revista Árvore, v.31, p.209-220, 2007. DOI: $10.1590 /$ S0100-67622007000200003.

$\overline{\text { Received on April 8, } 2015 \text { and accepted on August 24, } 2016}$ 